\title{
Synthesis, Characterization and Determination of the Metal Ions Adsorption Capacity of Cellulose Modified with P-Aminobenzoic Groups
}

\author{
Gustavo Rocha de Castro ${ }^{\mathrm{a}}$, Ilton Luiz de Alcântara ${ }^{\mathrm{a}}$, Paulo dos Santos Roldan ${ }^{\mathrm{a}}$ \\ Dorotéia de Fátima Bozano ${ }^{\mathrm{b}}$, Pedro de Magalhães Padilha ${ }^{\mathrm{b}}$ * \\ Ariovaldo de Oliveira Florentino ${ }^{\text {b }}$ Julio Cesar Rocha ${ }^{\text {a }}$ \\ ${ }^{a} I Q-U N E S P$, Dept. of Analytical Chemistry, Araraquara - SP, Brazil \\ ${ }^{\mathrm{b}}$ IB-UNESP, Dept. of Chemistry and Biochemistry, C.P. 510, 18618-000 Botucatu - SP, Brazil
}

Received: February 5, 2003; Revised: October 5, 2003

\begin{abstract}
This paper describes the synthesis and characterization of $\mathrm{p}$-aminobenzoic modified cellulose (Cell-PAB), as well as the separation and preconcentration of $\mathrm{Cd}(\mathrm{II}), \mathrm{Cu}(\mathrm{II}), \mathrm{Ni}(\mathrm{II}), \mathrm{Pb}(\mathrm{II})$ and $\mathrm{Zn}(\mathrm{II})$ ions from an aqueous medium using a Cell-PAB bath and the column technique. The quantity of p-aminobenzoic groups attached to the cellulose surface, i.e., $1.81 \pm 0.04 \mathrm{mmol} / \mathrm{g}$, was determined by elemental analysis. The FT-IR spectra of Cell-PAB revealed characteristic bands of paminobenzoic groups, indicating the desired functionalization of the cellulose surface. The adsorptive capacities for the metals ( $\mathrm{Ns}) \mathrm{Cd}, \mathrm{Cu}, \mathrm{Ni}, \mathrm{Pb}$ and $\mathrm{Zn}(\mathrm{Ns})$ were, respectively, $1.72 \pm 0.02$, $1.96 \pm 0.02,1.88 \pm 0.04,2.01 \pm 0.03$ and $1.93 \pm 0.03 \mathrm{mmol} / \mathrm{g}$. Metal separations performed in flow experiments using a column packed with $1 \mathrm{~g}$ of Cell-PAB and $5 \mathrm{~mL}$ of $1.5 \mathrm{~mol} / \mathrm{L} \mathrm{HCl}$ solution as eluent achieved an almost $100 \%$ metal ions recovery rate.
\end{abstract}

Keywords: modified cellulose, separation of heavy metals, preconcentration, adsorption, p-aminobenzoic groups

\section{Introduction}

Preconcentration by separation of dissolved trace element ions onto a chemically modified solid support has been studied intensively in recent years ${ }^{1-13}$. Cellulose is a particularly attractive solid support because of its mechanical and chemical stability and its availability in pure and diverse physical forms. Its surface is easily modified through low cost chemical processes, resulting in a considerable ion exchange capacity ${ }^{3,6}$. The active hydroxyl groups in the $\mathrm{C}_{5}$ atom present in the monomer of cellulose have the ability to react with suitable groups of organic ligands. These covalently bonded ligands are resistant to removal from the surface by organic solvents or water ${ }^{3}$.

The principal success of this solid modified support with organofunctional groups is the immobilization of the desired reactive atomic group, which renders this surface highly versatile in developing various functions ${ }^{13}$. Thus, functional groups containing nitrogen ${ }^{1,2}$, sulfur ${ }^{9}$, oxygen ${ }^{3,4}$ and phosphorus $^{6}$ arranged in cellulose chains render the surface useful for a variety of academic and industrial applications. Moreover, the majority of these anchored molecules contain nitrogen or oxygen or a combination of the two, which can bind metal ions in mono- or polydentate fashion ${ }^{1-4,7,10,12,13}$. Some of these modified cellulose surfaces facilitate the extraction of metal ions from aqueous and non-aqueous mediums $^{2,3,6,7,10}$.

This paper reports on the synthesis and characterization of p-aminobenzoic modified cellulose (Cell-PAB) aiming to find an efficient material for the separation and pre-concentration of $\mathrm{Cd}(\mathrm{II}), \mathrm{Cu}(\mathrm{II}), \mathrm{Ni}(\mathrm{II}), \mathrm{Pb}(\mathrm{II})$ and $\mathrm{Zn}$ (II) ions from an aqueous medium. The separation capabilities of Cell-PAB were first characterized through batch experiments and trace/matrix separations in a flow system, using a syn-

*e-mail: padilha@ibb.unesp.br

Articles presented at the XV CBECIMAT, Natal - RN, November de 2002. 
thetic aqueous solution containing the metal ions. The metals $\mathrm{Cd}(\mathrm{II}), \mathrm{Cu}(\mathrm{II}), \mathrm{Ni}(\mathrm{II}), \mathrm{Pb}(\mathrm{II})$ and $\mathrm{Zn}$ (II) were then determined in river water samples through a combination of the Cell-PAB flow system with flame atomic absorption spectrometry (FAAS).

\section{Experimental}

\subsection{Preparation of Modified Cellulose $e^{14}$}

Microcrystalline cellulose (Merck, Germany) with a specific surface area of $22 \mathrm{~m}^{2} \cdot \mathrm{g}^{-1}$ was activated at $353 \mathrm{~K}$ under a vacuum $\left(10^{-3}\right.$ Torr). About $16 \mathrm{~g}$ of this cellulose was immersed in $100 \mathrm{~mL}$ of purified dimethylformamide (Mallinckrodt, Germany) to which $30 \mathrm{~mL}$ of phosphorus oxychloride (Merck, Germany) was added. The mixture was refluxed in a glycerin bath for $16 \mathrm{~h}$ at $383-423 \mathrm{~K}$, filtered, washed with ethanol (Merck, Germany) and vacuum dried on filter paper. The resulting solid was immersed in $200 \mathrm{~mL}$ of purified dimethylformamide with the addition of $14 \mathrm{~g}$ of sodium p-aminobenzoate (Merck, Germany). This mixture was then stirred for $35 \mathrm{~h}$ at $423 \mathrm{~K}$. The resulting modified cellulose, called Cell-PAB, was filtered, washed with dimethylformamide and ethanol and then dried. Eq. 1 and 2 and 3, below, describe the preparation of the material:

$$
3 \mathrm{Cel}-\mathrm{CH}_{2} \mathrm{OH}+\mathrm{POCl}_{\substack{\text { DMF } 383 \mathrm{~K} \\ \rightarrow}} \mathrm{Cel}-\mathrm{CH}_{2}-\mathrm{Cl}+\mathrm{H}_{3} \mathrm{PO}_{4}
$$

$$
\begin{aligned}
& 3 \mathrm{Cel}-\mathrm{CH}_{2} \mathrm{Cl}+3 \mathrm{H}_{2} \mathrm{~N}-\left(\mathrm{C}_{6} \mathrm{H}_{4}\right)-\mathrm{COONa} \rightarrow 3 \mathrm{Cel}-\mathrm{CH}_{2}-\mathrm{NH}- \\
& \left(\mathrm{C}_{6} \mathrm{H}_{4}\right)-\mathrm{COONa}+3 \mathrm{HC} \quad \mathrm{DMF} / 383 \mathrm{~K} \\
& 3 \mathrm{Cel}-\mathrm{CH}_{2}-\mathrm{NH}-\left(\mathrm{C}_{6} \mathrm{H}_{4}\right)-\mathrm{COONa}+3 \mathrm{HCl} \rightarrow 3 \mathrm{Cel}-\mathrm{CH}_{2}- \\
& \mathrm{NH}-\left(\mathrm{C}_{6} \mathrm{H}_{4}\right)-\mathrm{COOH}+3 \mathrm{NaCl}
\end{aligned}
$$

\subsection{Characterization}

The quantity of p-aminobenzoic groups attached to the cellulose surface was determined by nitrogen elemental analysis, using a SHIMADZU EA-2218 CHNS-O elemental analyzer. The specific surface area was determined by the BET method ${ }^{15}$, using a Micromeritics ASAP 2010 apparatus (Micromeritics Instrument Corporation).

\subsection{Infrared spectra}

Diffuse reflectance infrared Fourier Transform (DRIFT) spectra were obtained with a Nicolet model Nexus 670 spectrometer with Smart Collector, in Kubelka-Munk units, with $1 \mathrm{mg}$ of material mixed with $500 \mathrm{mg}$ of $\mathrm{KBr}^{16}$.

\subsection{Exchange of metal ions by Cell-PAB}

The exchange of $\mathrm{M}$ metal ions from a solution by CellPAB can be described by an equilibrium equation of type $4^{17}$ :

$$
\text { Cell-PAB }_{(s)}+\mathrm{M} \underset{\text { Loads omitted for simplicity }}{\rightleftharpoons}(\text { Cell-PAB })+\mathrm{H}
$$

According to the equilibrium shown in Eq. 4, the ionization of the p-aminobenzoic group of Cell-PAB depends on the $\mathrm{pH}$ of the medium. The time required for this exchange reaction to reach equilibrium was previously determined by immersing $100 \mathrm{mg}$ of Cell-PAB in $50 \mathrm{ml}$ of $5 \times 10^{-3} \mathrm{~mol} / \mathrm{L}$ of the metal solution under study and shaking it. After various time intervals, an aliquot of the supernatant solution was separated and the metal ion was analyzed by complexometric titration, using EDTA as the titrant. The quantity of adsorbed metal separated per unit mass of the adsorbent, $\mathrm{N}_{\mathrm{f}}$, was calculated based on the following equation:

$$
\mathrm{N}_{\mathrm{f}}=\frac{\mathrm{N}_{\mathrm{i}}-\mathrm{N}_{\mathrm{s}}}{\mathrm{m}}
$$

where $\mathrm{N}_{\mathrm{i}}$ represents the initial mole number of the metal ion in the solution phase, $\mathrm{N}_{\mathrm{s}}$ is the mole number of the metal ion in equilibrium with the solid phase, and $\mathrm{m}$ is the adsorbent mass.

\subsection{Adsorption isotherms}

The adsorption capacity of Cell-PAB was determined at $298 \mathrm{~K}$, using the batch technique ${ }^{1}$. About $100 \mathrm{mg}$ of CellPAB were mixed with $50 \mathrm{~mL}$ of aqueous solutions of the metal under study (concentrations between $2.0 \times 10^{-4}$ and $2.5 \times 10^{-3} \mathrm{~mol} / \mathrm{L}$ ) and the resulting mixture shaken for $10 \mathrm{~min}$. The solid phase was separated by centrifugation and the metal ions determined in the supernatant solution by complexometric titration, as described earlier.

\subsection{Column preconcentration and recovery of heavy metal ions}

Column preconcentration was carried out using a $15 \mathrm{~cm}$ long, $0.6 \mathrm{~cm}$ inner diameter glass column packed with $1 \mathrm{~g}$ of Cell-PAB (with an $8 \mathrm{~cm}$ packing height). The column was first washed with high-purity water and then $50 \mathrm{~mL}$ of $50 \mu \mathrm{g} / \mathrm{L}$ of the metal $\mathrm{M}[\mathrm{M}=\mathrm{Cd}(\mathrm{II}), \mathrm{Cu}(\mathrm{II}), \mathrm{Ni}(\mathrm{II}), \mathrm{Pb}(\mathrm{II})$ and $\mathrm{Zn}(\mathrm{II})]$ in aqueous solutions were percolated through the column at a flow rate of $1.0 \mathrm{~mL} / \mathrm{min}$. Afterwards, the column was washed with $50 \mathrm{~mL}$ of water and the metal eluted with $5 \mathrm{~mL}$ of $0,25,0,5,1,0,1,5$ and $2,0 \mathrm{~mol} / \mathrm{L} \mathrm{HCl}$ solutions. All the fractions obtained during the elution stage were collected separately and analyzed by Flame AAS.

\subsection{Determination by FAAS}

The concentrations of metal ions extracted from the CellPAB column were determined by Flame AAS, according to the standard guidelines of the manufacturers (Spectrometer: SHIMADZU AA-6800), choosing prominent resonance 
lines for the metals and a deuterium-arc lamp for background correction. For the calibration, synthetic standard solutions comparable to the samples were used.

\subsection{Preconcentration and determination of heavy metals in natural water samples}

Samples collected from natural fresh water (Tietê River SP, Brazil) were immediately filtered through a $0.45 \mu \mathrm{m}$ membrane, then acidified $(\mathrm{pH}<2.0)$ with a $3.0 \mathrm{~mol} / \mathrm{L} \mathrm{HNO}_{3}$ solution and stored in highly purified PE containers. The $500 \mathrm{~mL}$ of river water samples were digested by photocatalysis in the presence of $10 \mathrm{mg}$ of $\mathrm{TiO}_{2}$, using a low-pressure Hg-lamp integrated in a closed quartz vessel ${ }^{18}$. The preconcentration experiments were carried out by percolating $100 \mathrm{~mL}$ of water samples (digested by photocatalysis or undigested) through the column packed with $1 \mathrm{~g}$ of Cell$\mathrm{PAB}$. The adsorbed metal ions were eluted with $5 \mathrm{~mL}$ of $1.00 \mathrm{~mol} / \mathrm{L} \mathrm{HCl}$ solution and the concentration of metal ions was determined by FAAS.

\section{Results and Discussion}

\subsection{Characteristics of the material}

The infrared spectra shown in Fig. 1 confirm the desired functionalization of the cellulose surface by PAB. The absorption band observed at $2901 \mathrm{~cm}^{-1}$ is due to the C-H vibration stretch of the $-\mathrm{CH}_{2}$ groups from primary alcohols. This band practically disappears in the Cell-PAB infrared spectra, indicating the decrease of $-\mathrm{CH}_{2}-\mathrm{OH}$ from the polymer monomers as a result of the functionalization. The other band of interest is observed at $2000-2100 \mathrm{~cm}^{-1}$, where a comparison of the two spectra reveals modifications, with emphasis on the band located at $1750 \mathrm{~cm}^{-1}$, which is attributed to the axial deformation vibration of $\mathrm{C}=\mathrm{O}$ from carboxylic acids.

The chemical analysis of nitrogen in Cell-PAB showed

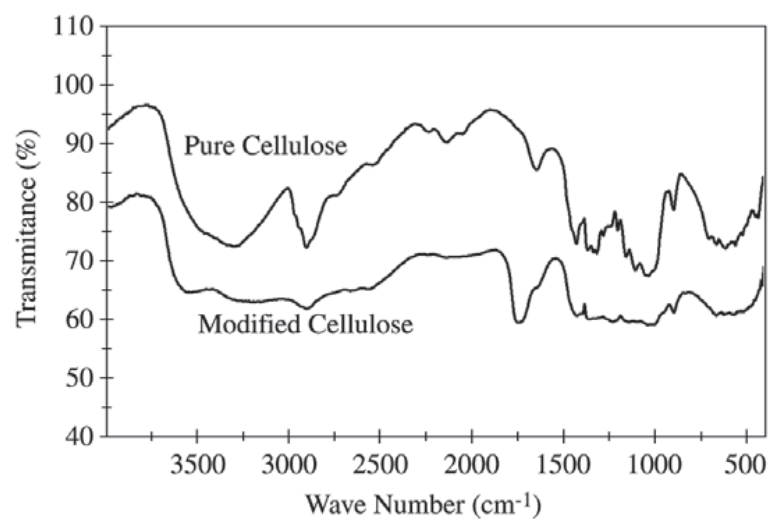

Figure 1. Infrared spectra of pure cellulose and cellulose modified with p-aminobenzoic groups. a content of $1,81 \pm 0,04 \mathrm{mmol} / \mathrm{g}$ of functional groups attached to cellulose surface. The specific surface was found to be $10 \pm 0.06 \mathrm{~m}^{2} / \mathrm{g}$. The decrease in specific surface area observed in the modified cellulose was ascribed to the covering of pores of the adsorbent by anchormen of p-aminobenzoic groups, which reduced the adsorption of $\mathrm{N}_{2}$ molecules used in the $\mathrm{S}_{\mathrm{BET}}$ measurement process ${ }^{19}$.

\subsection{Optimization of adsorption time}

One important aspect of metal separation in ion exchangers is the rate at which the exchanger adsorbs metal cations from the solutions and the time required to reach equilibrium $^{3,6,7}$. As a typical example of metal separation on CellPAB, Fig. 2 shows $\mathrm{Cu}$ (II) separation in this collector as a function of time. This exchange system reaches an equilibrium condition within 5 to $10 \mathrm{~min}$ due to the fast exchange kinetics of Cell-PAB.

\subsection{Effect of varying the $p H$}

As can be seen from Fig. 3, the separation of metal ions on Cell-PAB decreases considerably as the acidity of the medium increases. A pH value of 5 in the sample solution is apparently optimal for the separation of $\mathrm{Cu}$ (II) ions. Experiments at $\mathrm{pH}$ values of over 5 were not carried out because of the risk of undesirable hydrolysis and metal hydroxide precipitation ${ }^{3}$.

\subsection{Adsorption isotherms}

The ionic exchange capacity of Cell-PAB was also characterized by its capacity to adsorb the metal ions studied here. This adsorption capacity was determined from the saturation range of the metal loading isotherms shown in Fig. 4

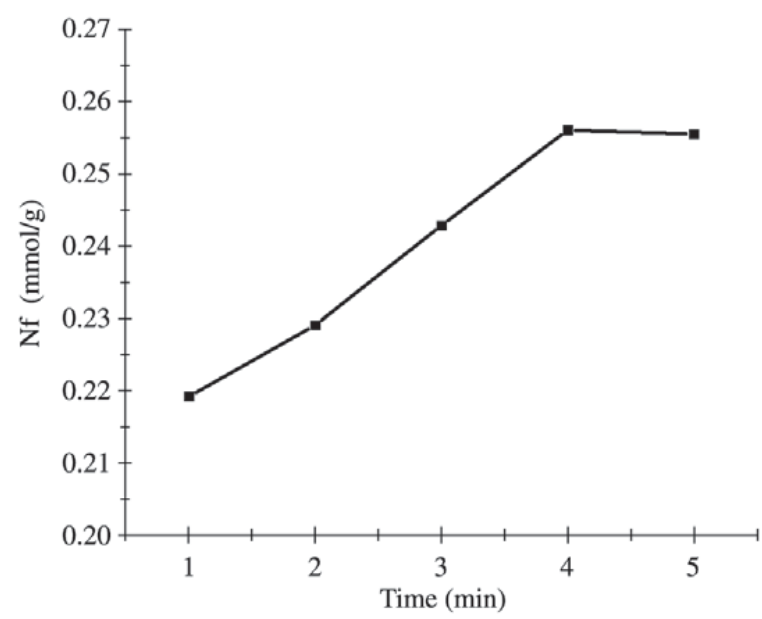

Figure 2. Plots of $\mathrm{N}_{\mathrm{f}}$ versus time for $\mathrm{Cu}$ (II) from na aqueous solution at room temperature. 
(in $\mathrm{mmol} / \mathrm{g}$ ): $1.60 \pm 0.02,1.86 \pm 0.04,1.76 \pm 0.03$, $1.92 \pm 0.04$ and $1.60 \pm 0.02 \mathrm{mmol} / \mathrm{g}$ for $\mathrm{Cd}, \mathrm{Cu}, \mathrm{Ni}, \mathrm{Pb}$ and $\mathrm{Zn}$, respectively. For the series of isotherms, the data reveal that the adsorption process conforms to the Langmuir model, as proposed for a series of systems ${ }^{20}$.

$$
\mathrm{C}_{\mathrm{s}} / \mathrm{N}_{\mathrm{f}}=\mathrm{C}_{\mathrm{s}} / \mathrm{N}_{\mathrm{s}}+1 / \mathrm{N}_{\mathrm{s}} \mathrm{b}
$$

In this expression, $\mathrm{Cs}$ is the concentration of solution in equilibrium ( $\mathrm{mmol} / \mathrm{L}), \mathrm{Nf}$ the concentration of metal ions adsorbed on the surface ( $\mathrm{mmol} / \mathrm{g})$, Ns the maximum amount of metal ions adsorbed per gram of adsorbent $(\mathrm{mmol} / \mathrm{g})$, which depends on the number of adsorption sites, and $b$ is a constant. All these adsorption studies were based on the linearized form of the adsorption isotherm derived from the $\mathrm{C}_{\mathrm{s}} / \mathrm{N}_{\mathrm{f}}$ as a function of the Cs plot. From these data, repre-

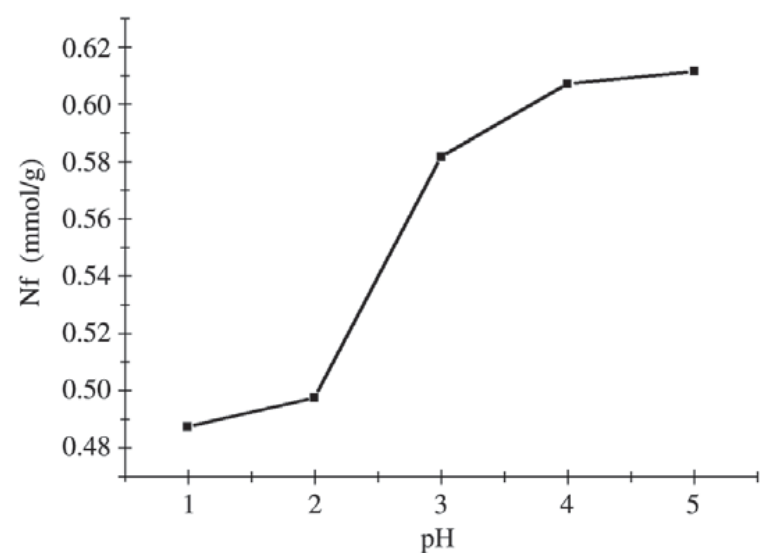

Figure 3. Effect of the $\mathrm{pH}$ value on sorption of $\mathrm{Cu}$ (II) ions onto Cell-PAB at room temperature.

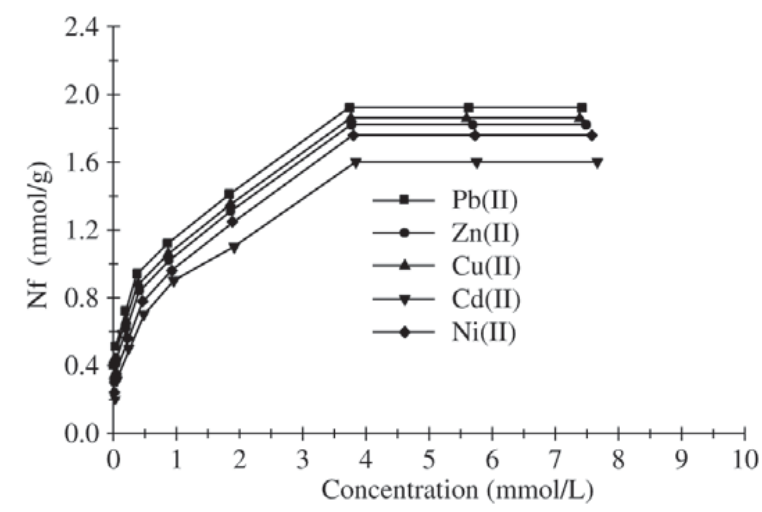

Figure 4. Exchange equilibrium of $\mathrm{Cu}(\mathrm{II}), \mathrm{Cd}(\mathrm{II}), \mathrm{Ni}(\mathrm{II}), \mathrm{Pb}(\mathrm{II})$ and $\mathrm{Zn}(\mathrm{II})$, respectively, between Cell-PAB and aqueous solution at room temperature. sented in Fig. 5, the maximum adsorption capacity (Ns) of each metal ion-carboxylate or metal ion-amino interaction was determined by applying the modified Langmuir equation, where Ns was obtained from the angular coefficient and $b$ from the linear coefficient of the straight lines in Fig. 5. Table 1 summarizes the values of Ns and b calculated for metal ions.

The ratio of metal ions maximally bound to the functional groups of the ion exchanger can be characterized by Equation $7^{17}$ :

$$
\phi^{\max }=\mathrm{N}_{\mathrm{s}} / \mathrm{N}_{\mathrm{o}}
$$

Where $\mathrm{N}_{\mathrm{o}}$ is the amount of functional groups (mmol) per mass of Cell-PAB (g). The metals' $\mathrm{f}^{\text {max. }}$ values were: $\mathrm{Cd}=0.95, \mathrm{Cu}=1.08$, $\mathrm{Ni}=1.03, \mathrm{~Pb}=1.11$ and $\mathrm{Zn}=1.06$. Since the metal ions all showed $\mathrm{f}^{\max } @ 1$, it can be assumed that the complexes formed were of the type metal/ligand $=1: 1$. This assumption is reasonable when one considers that the metal can coordinate in two possible ways: in the nitrogen atoms of amino groups or in the carboxylate groups ${ }^{21}$.

\subsection{Recovery and determination of heavy metal ions}

Table 2 summarizes the metal recovery experiments performed by the column procedure, using the Cell-PAB collec-

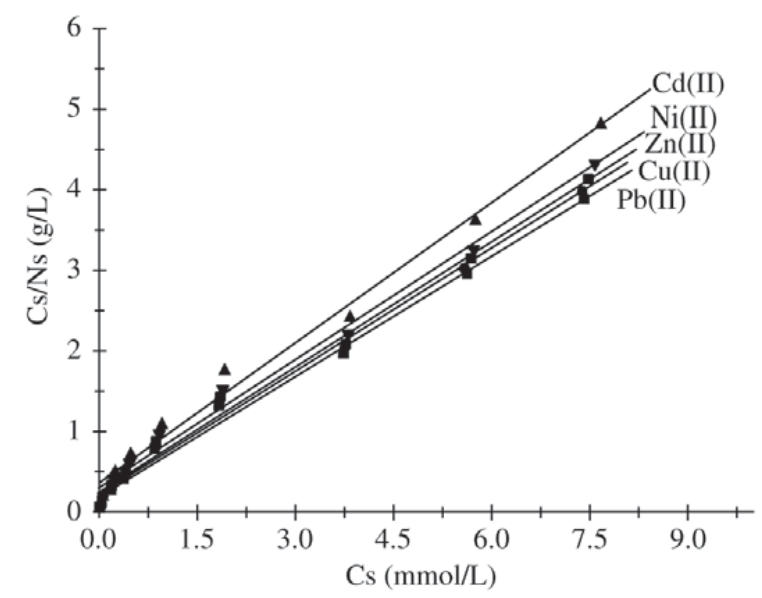

Figure 5. Linearization of adsorption isotherms of $\mathrm{Cd}(\mathrm{II}), \mathrm{Cu}(\mathrm{II})$, $\mathrm{Ni}(\mathrm{II}), \mathrm{Pb}$ (II) and $\mathrm{Zn}$ (II) in aqueous solution on Cell-PAB surface at room temperature.

Table 1. Adsorption per gram of Cell-PAB surface (Ns) for metal ions in aqueous medium.

\begin{tabular}{ccc}
\hline Metal Ions & Ns $-\mathrm{mmol} / \mathrm{g}$ & Constant $-\mathrm{b}$ \\
\hline $\mathrm{Cd}(\mathrm{II})$ & $1.72 \pm 0.02$ & 3.10 \\
$\mathrm{Cu}(\mathrm{II})$ & $1.96 \pm 0.02$ & 4.98 \\
$\mathrm{Ni}(\mathrm{II})$ & $1.88 \pm 0.04$ & 3.67 \\
$\mathrm{~Pb}(\mathrm{II})$ & $2.01 \pm 0.03$ & 5.73 \\
$\mathrm{Zn}(\mathrm{II})$ & $1.93 \pm 0.03$ & 4.55 \\
\hline
\end{tabular}


Table 2. Preconcentration factor of $\mathrm{Cu}(\mathrm{II}), \mathrm{Ni}(\mathrm{II}), \mathrm{Zn}(\mathrm{II}), \mathrm{Cd}(\mathrm{II})$ and $\mathrm{Pb}(\mathrm{II})$ obtained using a column packed with Cell-PAB. Experimental Conditions: Metal Ions Concentration $=50 \mu \mathrm{g} / \mathrm{L}$ of $\mathrm{Cu}(\mathrm{II}), \mathrm{Ni}(\mathrm{II}), \mathrm{Zn}(\mathrm{II}), \mathrm{Cd}(\mathrm{II})$ and $\mathrm{Pb}(\mathrm{II})$; Preconcentrated volume $=50 \mathrm{~mL}$; Eluent -5 $\mathrm{mL}$ of $\mathrm{HCl}$ solutions in different concentration; Flow Rate $-1.0 \mathrm{~mL} / \mathrm{min}$.

\begin{tabular}{|c|c|c|c|c|c|c|}
\hline \multirow[t]{2}{*}{$\begin{array}{c}\text { Percolated } \\
\text { Volume }(\mathrm{mL})\end{array}$} & \multirow{2}{*}{$\begin{array}{c}\text { Eluent } \\
\text { Concentration } \\
(\mathrm{mol} / \mathrm{L}) \mathrm{HCl} \\
\end{array}$} & \multicolumn{5}{|c|}{ Eluent Concentration $(\mu \mathrm{g} / \mathrm{L})$} \\
\hline & & $\mathrm{Cu}$ & $\mathrm{Cd}$ & $\mathrm{Ni}$ & $\mathrm{Pb}$ & $\mathrm{Zn}$ \\
\hline \multirow{4}{*}{50} & 0,25 & $507 \pm 8$ & $496 \pm 6$ & $390 \pm 5$ & $418 \pm 8$ & $504 \pm 9$ \\
\hline & 0,50 & $508 \pm 9$ & $498 \pm 5$ & $447 \pm 6$ & $451 \pm 9$ & $504 \pm 8$ \\
\hline & 1,00 & $502 \pm 6$ & $501 \pm 7$ & $502 \pm 6$ & $506 \pm 10$ & $501 \pm 8$ \\
\hline & 1,50 & $505 \pm 7$ & $499 \pm 5$ & $510 \pm 7$ & $509 \pm 11$ & $503 \pm 9$ \\
\hline
\end{tabular}

Table 3. Preconcentration by Cell-PAB flow procedure followed by FAAS in river water samples (with and without photocatalytic digestion, $100 \mathrm{~mL}$ sample, $\mathrm{n}=3$ ).

\begin{tabular}{rcccccc}
\hline Metal & \multicolumn{2}{c}{ Sample-1 $(\mu \mathrm{g} / \mathrm{L})$} & \multicolumn{2}{c}{ Sample-2 $(\mu \mathrm{g} / \mathrm{L})$} & \multicolumn{2}{c}{ Sample-3 $(\mu \mathrm{g} / \mathrm{L})$} \\
\hline $\mathrm{Cd}$ & $2 \pm 0.08$ & $\mathrm{n} . \mathrm{d}^{*}$ & $2 \pm 0.06$ & $\mathrm{n} . \mathrm{d}^{*}$ & $2 \pm 0.07$ & $\mathrm{n} . \mathrm{d}^{*}$ \\
$\mathrm{Cu}$ & $14 \pm 0.7$ & $9 \pm 0.40^{*}$ & $13 \pm 0.6$ & $8 \pm 0.20^{*}$ & $14 \pm 0.6$ & $10 \pm 0.40^{*}$ \\
$\mathrm{Ni}$ & $12 \pm 0.4$ & $8 \pm 0.24^{*}$ & $13 \pm 0.4$ & $10 \pm 0.40^{*}$ & $13 \pm 0.5$ & $8 \pm 0.20^{*}$ \\
$\mathrm{~Pb}$ & $5 \pm 0.1$ & $3 \pm 0.06^{*}$ & $4 \pm 0.09$ & $2 \pm 0.07^{*}$ & $5 \pm 0.09$ & $2 \pm 0.06^{*}$ \\
$\mathrm{Zn}$ & $70 \pm 4$ & $44 \pm 2^{*}$ & $62 \pm 3$ & $34 \pm 2^{*}$ & $67 \pm 3$ & $52 \pm 2^{*}$ \\
\hline
\end{tabular}

n.d, not detected; * not digested by photocatalysis

tor, and $5.0 \mathrm{~mL}$ of $0.25,0.50,1.00$ and $1.50 \mathrm{~mol} \mathrm{~L}^{-1} \mathrm{HCl}$ as eluent. As can be seen, practically $100 \%$ recovery was achieved for all the metal ions studied. The preconcentration factors calculated were 10.1, 10, 10.2, 10.3 and 10 for $\mathrm{Cu}$ (II), $\mathrm{Ni}(\mathrm{II}), \mathrm{Zn}(\mathrm{II}), \mathrm{Pb}(\mathrm{II})$ and $\mathrm{Cd}(\mathrm{II})$, respectively. The precision, expressed as RSD for fifty independent determinations (column runs), was $2 \%$ for $50 \mu \mathrm{g} / \mathrm{L}$ of $\mathrm{Cd}(\mathrm{II}), \mathrm{Cu}$ (II), $\mathrm{Ni}(\mathrm{II}), \mathrm{Pb}$ (II) and $\mathrm{Zn}$ (II). A linear calibration curve was obtained in the 10 $-100 \mu \mathrm{g} / \mathrm{L}$ range for $\mathrm{Cd}(\mathrm{II}) / \mathrm{Zn}$ (II), 20 - $200 \mu \mathrm{g} / \mathrm{L}$ for Cu(II)/ $\mathrm{Ni}$ (II) and $50-250 \mu \mathrm{g} / \mathrm{L}$ for $\mathrm{Pb}$ (II), preconcentrated under the same conditions as described earlier herein. The results obtained are shown in Fig. 6. The detection limits calculated (in relation to the blanks of elements) under these conditions were $0.21,1.13,0,60,2.40$ and $0.34 \mu \mathrm{g} / \mathrm{L}$ for $\mathrm{Cd}(\mathrm{II}), \mathrm{Cu}(\mathrm{II})$, $\mathrm{Ni}(\mathrm{II}), \mathrm{Pb}(\mathrm{II})$ and $\mathrm{Zn}(\mathrm{II})$, respectively.

\subsection{Preconcentration and determination of heavy metal ions in natural samples}

A series of determinations of metal ions in river water samples (from the Tietê river in the state of São Paulo, Brazil) were carried out by combining preconcentrations in the Cell-PAB flow system with FAAS. The results of these determinations are summarized in Table 3 . The concentrations of $\mathrm{Cd}$ and $\mathrm{Pb}$ were relatively low in the analyzed samples, but clearly above the detection limits of this procedure.

As Table 3 indicates, the Cell-PAB-FAAS determinations
Table 4. Determination of metals in river water samples by GFAAS after photocatalytic digestion of the samples (direct determination, $\mathrm{n}=3$ ).

\begin{tabular}{cccc}
\hline Metals & $\begin{array}{c}\text { Sample-1 } \\
(\mu \mathrm{g} / \mathrm{L})\end{array}$ & $\begin{array}{c}\text { Sample-2 } \\
(\mu \mathrm{g} / \mathrm{L})\end{array}$ & $\begin{array}{c}\text { Sample-3 } \\
(\mu \mathrm{g} / \mathrm{L})\end{array}$ \\
\hline $\mathrm{Cd}$ & $1.50 \pm 0.03$ & $1.60 \pm 0.02$ & $1.4 \pm 0.03$ \\
$\mathrm{Cu}$ & $15 \pm 0.6$ & $14 \pm 0.5$ & $15 \pm 0.5$ \\
$\mathrm{Ni}$ & $13 \pm 0.4$ & $14 \pm 0.6$ & $15 \pm 0.3$ \\
$\mathrm{~Pb}$ & $6 \pm 0.06$ & $5 \pm 0.04$ & $6 \pm 0.06$ \\
$\mathrm{Zn}$ & $70 \pm 3$ & $62 \pm 2$ & $67 \pm 2$ \\
\hline
\end{tabular}

in undigested river water samples revealed metal concentrations 16 to $25 \%$ lower than in the digested samples. The difference between these results was attributed to the formation of inert complexes of metal ions with aquatic humic substances (HS), a process that is less accessible to the functional groups of the collector ${ }^{22}$. After digestion (by oxidizing photocatalysis), metal ions bound to HS as inert complexes can quantitatively react with functional groups of Cell-PAB. These findings are congruous with results obtained by direct determination with GFAAS (Graphite Furnace Absorption Atomic Spectrometry), also shown in Table 4.

\section{Conclusions}

P-aminobenzoic groups immobilized on a cellulose sur- 


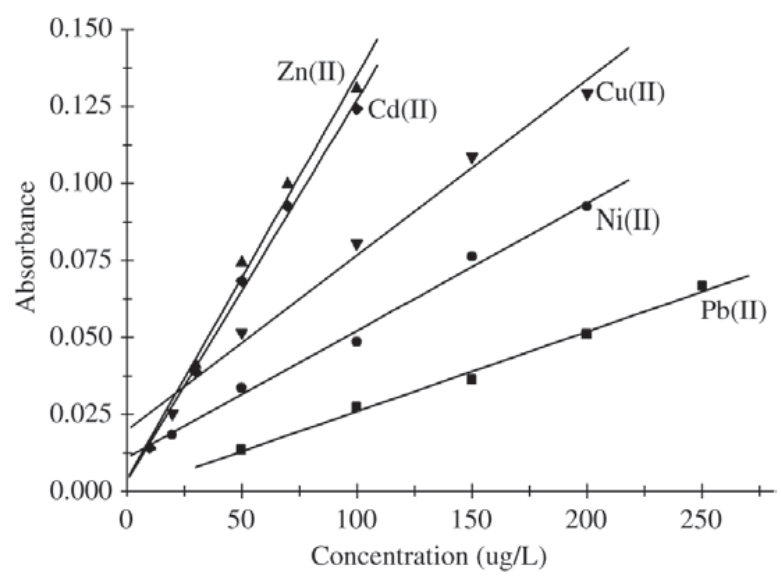

Figure 6. Calibration graphs obtained after preconcentration on a Cell-PAB column. Experimental conditions: $1 \mathrm{~g}$ Cell-PAB column, $1.0 \mathrm{~mol} / \mathrm{L} \mathrm{HCl}$ as eluent, flow rate of eluent $1.0 \mathrm{~mL} / \mathrm{min}$, sampling flow rate $1.0 \mathrm{~mL} / \mathrm{min}$.

face can easily be used to separate heavy metal ions from aqueous solutions. The relatively high chemical stability of Cell-PAB in water, as well as the fast kinetics whereby heavy ions can be separated, renders this material potentially useful for analytical purposes. Moreover, the use of a column preconcentration technique allows for the assessment of low trace metal concentrations, even by less sensitive determination methods such as flame AAS. Preconcentration by this material (Cell-PAB) from river water samples, however, requires prior digestion of the samples by sample oxidizing photocatalysis.

\section{Acknowledgments}

The authors thank the Brazilian research funding agencies FAPESP (Process 98/14789-3 and 99/12916-0) and CNPq for the fellowships granted to Castro, G. R.

\section{References}

1. Schrammel, P., Knapp, G.; Fresenius J. Anal. Chem., v. 345, p. 600-606, 1993.

2. Burba, P.; Rocha, J.C.; Schulte, A.; Fresenius J. Anal. Chem., v. 346, p. 414-419, 1993.
3. Padilha, P.M.; Campos, J.T.S.; Moreira, J.C.; Federici, C.C. Química Nova, v.18, n.6, p. 519-528, 1995.

4. Navarro, R.R.; Sumi, K.; Fujii, N.; Matsumura, M. Water Research, v. 30, p. 2488-2494, 1996.

5. Filho, U.P.R.; Gushikem, Y.; Gonçalves M.C.; Cachichi, R.C. Chem. Mater., v. 8, p. 1375-1379, 1996.

6. Padilha, P.M.; Rocha, J.C., Campos, J.T.S.; Moreira, J.C.; Federici, C.C., Talanta, v.45, p. 317-323, 1997.

7. Padilha, P.M.; Rocha, J.C.; Campos, J.T.S.; Moreira, J.C.; Federici, C.C. J. Braz. Chem. Soc., v. 8, p. 333-337, 1997.

8. Campos, E.A.; Gushikem, Y. J. Of. Colloid and Interface Science, v. 193, p. 121-126, 1997.

9. Perényi, K.Z.; Lásztity, A.; Lévai, Z.H. Talanta, v. 47, p. 673-679,1998.

10. Padilha, P.M.; Rocha, J.C.; Federici, C.C. Química Analítica, v. 18, p. 299-303, 1999.

11. Toledo, E.A.; Gushikem, Y.; Castro, S.C. J. Of. Colloid and Interface Science, v. 225, p. 455-459, 2000.

12. Eromosele, I.C.; Bayero, S.S. Bioresource Technology, v. 71, p. 279-281, 2002.

13. Navarro, R.R.; Tatsumi, K.; Sumi, K.; Matsumura, M. Water Research, v. 35, p. 2724-2730, 2001.

14. Smits, J.; Grieken, Van R. Makromol Chem., v. 72, p. 105, 1978.

15. Brunaur, S.; Emmet, P.; Teller, E. J. Am. chem. Soc., v. 60, p. 309-315, 1938.

16. Gushikem, Y.; Moreira, J.C. J. Coll. Interface Sci., v. 13, p. 70-74, 1985.

17.Padilha, P.M.; Gomes, L.A.M.; Padilha, C.C.F.; Moreira, J.C.; Filho, N.L.D. Anal. Lett., v. 32(9), p. 1807-1820, 1999.

18. Burba, P.; Milmer, R.E. Z. Frezenius Anal. Chem., v. 311, p. 738-742, 1982.

19. Gomes, L.A.M.; Padilha, P.M.; Moreira, J.C.; Filho, N.L.D.; Gushikem, Y. J. Braz. Chem. Soc., v. 9, n. 5, p. 494-498, 1998.

20. Prado, A.G.S.; Airoldi, C. Anal. Chim. Acta., v. 423, p. 201-211, 2001.

21. Roldan, P.S.; Alcântara, I.L.; Castro, G.R; Rocha, J.C.; Padilha, C.C.F., Padilha, P.M. Anal. and Bioan. Chem., v. 375, n. 4, p. 574-577, 2003.

22. Toscano, I.A.S.; Rocha, J.C.; Burba, P. Talanta, v. 44, p. 65-69, 1997. 